\title{
Factors Influencing Young Job Seekers Perception towards Job Portals
}

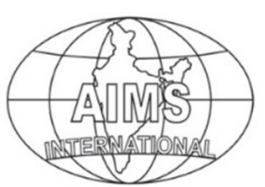

DOI: $10.26573 / 2018.12 .3 .5$

Volume 12, Number 3

September 2018, pp. 199-212

\author{
Seema Wadhawan \\ Smrita Sinha \\ Amity University \\ (seema.nangia78@gmail.com) \\ (Ssinha1@amity.edu.in)
}

Post LPG era organizations have been witnessed by technological changes. These changes have many influences; one of the vital influence is on recruitment program undertaken by the organizations on one end and job search activity undertaken by millennial job seekers on the other end. Online recruitment has become an important platform for hunting best talent. Thus it is imperative to study and identify the factors affecting online job search among students of Delhi from state and private university. A total of 150 respondents administered to the online questionnaire. To analyze the data, statistical tools, viz Factor Analysis, One Way ANOVA and POST HOC were tested on IBM-SPSS 21. Result identified various factors affecting the perception of millennial and post millennial towards online recruitment and the significant difference among job seekers of different age group towards different factors.

Keywords: Online Recruitment, Online Job Search, Job Seekers Perception

\section{Introduction}

Recruitment refers to the process of searching the prospective job applicant and stimulating them to apply for jobs in an organization "Flippo". Recruitment is one of the vital functions of HR as it focuses on building resources such as human capital in an organization (Baber, 1998). With the growth of internet, it was anticipated that the future of recruitment will be on net (Edgeley, 1995).

E-recruitment or online recruitment refer to use of technology, internet or web based tools for the recruitment activities by various organization. Technology has enabled the organizations to search most appropriate and right fit by placing the advertisements or job postings on job portals and social networking sites. These employment portals provide a platform to both job applicants to search for jobs in various organizations at a time and help organizations to find the most appropriate applicants. Thus, bridging the gap between recruiter and job seekers. The cost and time benefit of these services is far beyond the boundaries of traditional recruitment methods. Yet there is dearth of research related to the manner in which the applicant search jobs online and derive satisfaction (Crossley and High house, 2005). Organizations follow technology based recruitment process to improve efficiency and reduce cost in its search for talent (Chapman and Webster 2003). 
Though the usage of internet by organizations has increased, yet efficiency of the research is still at its infancy. Today the Millennial and post Millennial are very selective. Various e-recruitment websites have become the vital platforms in the job search behavior. Thus, the purpose of this research is to study the factors affecting the job seekers perceptions towards online recruitment, with special reference to job portals especially Naukri.com.

Naukri.com is India's one of the most famous Job Searching platform. It was established in year 1997. The portal operates under the umbrella of Info Edge India Ltd and operates as an industry legend. Since its birth it has revolutionized the term of recruitment, providing solutions to employer for their effect applicant search on the other hand helping job seekers in their job search activity. Naukri.com has a huge database of about 49.5 million job seekers registered with it as on Dec 2016, where almost 11000 resumes are added daily, while 130,000 resumes are modified daily. 51000 corporate clients are associated with Naurki.com for their advertisement, access of databases and other services provided by Naukri.com

Naukri.com today provides various services. Apart from job search for applicants, it provides extended services, such as resume review, resume writing guidance, connect to mobile messages and many more. All these services are available with the objective of client and job applicant solutions.

\section{Review of Literature}

Schreyer and McCarter (1998) alludes that Internet recruitment is "the recruitment process, including placing job advertisements, receiving resumes, and building human resource databases with candidates and incumbents".

Zusman and Landis (2002) Stated in his research that high quality webpage, its design, appeal, look and color are some of the strong elements to attract the eyes of job and mostly influenced by headline information, such as salary and the brand name of the company. In congruence with this research, employment job portal "Naukri.com" in Indian context is currently using this strategy to attract a significant pool of graduate students by emphasizing salary and positions.

Lievens and Harris (2003) stated some five different perspective of Internet recruitment, such company websites, job boards, e-recruiting, relationship recruiting, and approaches.

Lee (2005) alludes that online recruitment is just posting of advertisement on the websites and instructions on how to apply for the open positions. With advancement in technology taking place, and Web 2.0 being available, there are now varied methods of online recruitment such as Employee Blogs, Twitter, Face book, LinkedIn, Job Portals and Company website. Through online recruitment the applicant can easily search for and apply for the open positions, matching his/her profile just at a mouse click. Most commonly preferred tools used by the applicant to gather the job information is the career section of company website and job boards or employment websites (naukri, monster, times. job etc). Career section of the website would be a useful tool for acquisition of talent when the company is a known brand and have image in the market. For new startups, small organizations and those who are not commonly a brand prefer to use job portals to create their applicant pool. It is essential to study how the reaction of job applicant is build towards e-recruitment with special reference to Job Portals. 
Allen et al., (2007) alludes that internet recruitment is highly effective, convenient, and efficient due to its natural cost saving compared with traditional and conventional recruitment approaches. Moreover, varied profit and non-profit organizations are looking at online recruitment as a main source for filling job vacancies, aiming to attract talented employees. On the other hand, job seekers' attitudes are influenced by certain online information available on the website of the company.

Thompson et al., (2008) stated that ease of navigation of online website is another important factor that leads to willingness to pursue a specific job. The more an online vendor's site is complicated the more individuals will switch to another portal. This indicates that site to contain functions that help customers find what they need without difficulty, possesses a good search engine, and allows the customer to maneuver easily and quickly back and forth through the pages.

Walker et al. (2011) suggested that characteristics of website and online recruitment methods would change the perception of job seekers about the company. In fact, the attractiveness of company web advertisement about job vacancies would change the behavior of applicants toward the company. Therefore, internet recruitment is recognized as an advantageous method over conventional approach for recruitment purpose.

S. Kapse, et. al., (2012) stated that E- Recruitment is the use of technology to assist the recruitment process. It enables the organization to advertise job vacancies through worldwide web. This article also insists that Job Portals are the most popular and widely used tool by companies and recruitment teams to facilitate the smooth flow of recruitment process in the competitive world. Job Portals provide a platform for the employers to meet the prospective employees. This system will help for betterment of traditional recruitment with less time and cost and will act as platform for both job seeker to search the job and corporate sector to hire appropriate candidates.

Dhamija (2012) made an attempt to examine the impact of E-HRM. For an organization human resources are the vital resource and management of its resources is of utmost importance. Use of technology has influenced the functioning, practices, procedures of HRM. It has led to various developments and innovations like HRIS, HR accounting, E-Recruitment and E-HRM. Indicating that E-HRM is a means of conducting varied activities in the organization.

Banerjee and Tiwari (2013) depicted that online recruitment has given rise to the issue of lack of credibility in comparison to traditional media such as newspapers and campus interviews. The authors emphasized on the variable of message credibility under e-recruitments. Where the focus of the study was to understand two areas within this platform of e-recruitment. Main attention was put on areas within these domains which were yet to be explored largely in context of e recruitment - a) Realistic employee testimonials and b) Company independent channels for hosting online job advertisements.

Moghaddam and Muslim (2013) the authors allude that E-Recruitment has turned to be an indispensible practice within organizations in various industries, considering the scope and importance of human resource capabilities for building competitive position of the organization. The study focused to examine the effect varied dimension such as information content qualities (ICQ), vividness (VID), 
interactivity (INT), attractiveness and effectiveness (EFE), search engine optimization (SEO), website ranking (WER), and ease of navigation (EN) on job seekers' perception and behavioral intention (BI).

Kumar and Priyanka (2014) conducted a study to understand the factors influencing the e-recruitment process. (TAM) Technology Acceptance Model was applied in this research, where the questionnaire was administered to a sample of 400 graduating students in different universities in Bahrain. Statistical tools like simple percentages, mean, standard deviation, multiple regressions, factor analysis and path analysis was used to analyze the data. The study found a significant relationship between perceived usefulness (PU), Attitude towards usage (ATU) and behavioral intention (ITU) to use the e-recruitment System. This study is a step towards examining students' perceptions of usage of an e-recruitment system that informs their attitude towards usage and their behavioral intention to using the system.

Kaur (2015) depicted that since inception online recruitment has come a long way. Online recruitment is the latest to remain competitive in the globalized era. The traditional methods of recruitment have been revolutionary through the influence of internet. Organizations today are competent with the use and its corresponding actions like email. The researcher via this paper makes an attempt to showcase the pros and cons of effective recruitment and the criteria used.

Patwardhan (2016) has made an attempt to investigate the influence (relation) of identified factors on job seekers, interacting / transacting with Monster.com. As an online job seeking avenue. Results of the study may be useful for Monster.com and for that matter for any job portal to successfully deliver offerings in the market place, to appreciate and correct perceptions of job seekers interacting / transacting with Monster.com, to discover job seekers' attitudes by understanding how they engage psychologically with the portal, how they acquire, evaluate and use job search information as well as job search experiences and finally, how job seekers make decisions to spend their available resources (time, money, effort) while employing the Monster.com as a job seeking avenue.

\section{Objectives of the Study}

1. To identify the factors influencing perception of job seekers towards online recruitment with special reference to naukri.com

2. To examine significant difference in perception of millennial job seekers of varied age groups towards naukri.com with reference to factors identified

\section{Research Methodology}

This study is descriptive in nature, where it focuses to identify various dimensions which are affecting the behavioural intentions of millennial and post millennial job seekers towards E-recruitment website with reference to employment job portal Naukri.com. Data was collected from both primary and secondary sources. For primary data the population of the study is the university students of Delhi. Convenience sampling was used. The respondents were final year semester students from state and private university. Data was collected over the period of 45 days, from 150 respondents through a self-constructed questionnaire, which was distributed via online platform. Only those responses were taken for the study which 
was complete. Respondents were asked to fill the questionnaire based on their experience towards job portal with special reference to Naukri.com.

Questionnaire was framed from previous researches, by incorporating variables like User Friendliness, Perceived Ease of Use, Information Provision, and Fairness Perception. It was divided into two sections; Section A and B, Where in Section A was to get the details about demographic data of the respondents. Section B reflected the items which build the behaviour intention. 5-point Likert scale was administered with 28 statements which were developed on the basis of literature review.

4.1 Demographic of Respondents

The descriptive Statistics which are discussed in the study consist of frequency and percentage of profiles of the respondents.

Table 1 Demographic Profile of the Respondents

\begin{tabular}{|c|c|c|c|c|}
\hline Demographic Features & $\begin{array}{c}\text { Number of } \\
\text { Respondents }\end{array}$ & Options & Frequency & Percentage \\
\hline \multirow{2}{*}{ Gender } & \multirow{2}{*}{150} & Female & 65 & 43 \\
\cline { 3 - 5 } & & Male & 85 & 57 \\
\hline \multirow{2}{*}{ Age } & \multirow{2}{*}{150} & Below18 & 12 & 8 \\
\cline { 3 - 5 } & & $18-21$ & 27 & 18 \\
\cline { 3 - 5 } & & $22-24$ & 90 & 60 \\
\cline { 3 - 5 } & & $25-28$ & 21 & 14 \\
\hline \multirow{2}{*}{$\begin{array}{c}\text { Highest Qualification } \\
\text { Completed }\end{array}$} & \multirow{2}{*}{150} & Schooling & 18 & 12 \\
\cline { 3 - 5 } & & Graduate & 66 & 44 \\
\cline { 3 - 5 } & & Prost & 62 & 41 \\
\cline { 3 - 5 } & & Others & 4 & 3 \\
\hline
\end{tabular}

Table 1 above shows the demographic details of the respondents according to gender, age and highest qualification. Of 150 respondents taken for the study 57 percent were male and 43 percent were females. 60 percent of the respondents were in age group of $22-24$ and 18 percent were in the age group of $18-21$. These two groups were the main contributor for the study. 44 percent of the respondents were graduate, followed by post graduate who were 41percent, then 12 percent who had completed schooling and 3 percent belong to the others group with respect to highest completed qualification.

\section{Statistical Analysis and Results}

IBM SPSS 21 (Statistical Package for the Social Sciences) was used for data analysis. Reliability and validity measure for the construct was done by using techniques of the Cronbach's Alpha and KMO Bartlett's test. EFA, Exploratory Factor analysis techniques were applied to extract the factors affecting the perception of millennial job seekers towards job portal. ANOVA analysis of variance to study the difference among population mean. 


\title{
5.1 Reliability of Questionnaire
}

Table 2 Cronbach's Alpha

\author{
Reliability Statistics
}

\begin{tabular}{|c|c|}
\hline Cronbach's Alpha & N of Items \\
\hline 0.852 & 28 \\
\hline
\end{tabular}

As per Table 2 Cronbach's Alpha value for the whole construct of questionnaire was 0.852 which is lying within the accepted value of 0.6 to 0.9 , to carry the research with this construct. So the questionnaire is found to be reliable for the study.

\subsection{Sampling Adequacy}

Table 3 KMO \& Bartlett's Test of Sphericity

\begin{tabular}{|l|l|c|}
\hline \multicolumn{3}{|c|}{ KMO and Bartlett's Test } \\
\hline Kaiser-Meyer-Olkin Measure of Sampling Adequacy. & 0.814 \\
\hline \multirow{3}{*}{ Bartlett's Test of Sphericity } & Approx. Chi-Square & 1364.528 \\
\cline { 2 - 3 } & Df & 378 \\
\cline { 2 - 3 } & Sig. & .000 \\
\hline
\end{tabular}

As per Table 3 KMO measure the sampling adequacy, the value of Kaiser-MeyerOlkin Measure is 0.814. KMO compares the sizes of observed correlation coefficient with the partial correlation coefficient. The value of 0.814 reflects the Figure is lying in the acceptable range of min 0.6 and max. 0.910. Bartlett's test of sphericity test whether it population correlation matrix is the identity matrix, existence of identity matrix gives the correctness of factor analysis. As per the Table 3 the value of chisquare is 1364.528 with 378 Degree of freedom at significance of 0.000 which is less that $\mathrm{p}<0.01$. Based on the result it is appropriate to proceed for factor analysis to examine the factors for the study.

\subsection{Factor Identification and Loading}

Table 4 Total Variance Explained

\begin{tabular}{|c|c|c|c|}
\hline \multicolumn{4}{|c|}{ Total Variance Explained } \\
\hline \multirow{2}{*}{ Component } & Rotation Sums of Squared Loadings \\
\cline { 2 - 4 } & Total & \% of Variance & Cumulative \% \\
\hline 1 & 2.762 & 9.865 & 9.865 \\
\hline 2 & 2.713 & 9.689 & 19.554 \\
\hline 3 & 2.703 & 9.654 & 29.207 \\
\hline 4 & 2.597 & 9.275 & 38.482 \\
\hline 5 & 2.522 & 9.006 & 47.488 \\
\hline 6 & 2.270 & 8.107 & 55.595 \\
\hline 7 & 2.179 & 7.782 & 63.378 \\
\hline Extraction Method: Principal Component Analysis \\
\hline
\end{tabular}


As per Table 4, the results display that the total variance explained by identified seven factors affecting the perception of millennial job seeker towards job portals. These factors were extracted for the study because their eigen value were greater than "1". The seven extracted factors were able to explain 63.378 Percent of variance.

Table 5 Rotated Component Matrix ${ }^{a}$

\begin{tabular}{|l|c|c|c|c|c|c|c|}
\hline & \multicolumn{7}{|c|}{ Component } \\
\hline & 1 & 2 & 3 & 4 & 5 & 6 & 7 \\
\hline Statement 1 & & .887 & & & & & \\
\hline Statement 2 & & .699 & & & & & \\
\hline Statement 3 & & .615 & & .583 & & & \\
\hline Statement 4 & & .549 & & & & & \\
\hline Statement 5 & & .546 & & & & & \\
\hline Statement 6 & .517 & & & & & & \\
\hline Statement 7 & & & .763 & & & & \\
\hline Statement 8 & & & .787 & & & & \\
\hline Statement 9 & & & .628 & & & & \\
\hline Statement 10 & & & & & & & \\
\hline Statement 11 & & & & .676 & & & \\
\hline Statement 12 & & & & .729 & & & \\
\hline Statement 13 & & & & .555 & & & \\
\hline Statement 14 & & & & & & & \\
\hline Statement 15 & & & & & .814 & & \\
\hline Statement 16 & & & & & .616 & & \\
\hline Statement 17 & & & & & .555 & & .455 \\
\hline Statement 18 & & & & & & & .671 \\
\hline Statement 19 & & & & & & & .674 \\
\hline Statement 20 & & & & & .515 & & .615 \\
\hline Statement 21 & .694 & & & & & & \\
\hline Statement 22 & .779 & & & & & & \\
\hline Statement 23 & .748 & & & & & & \\
\hline Statement 24 & .673 & & & & & & \\
\hline Statement 25 & & & & & & & -.595 \\
\hline Statement 26 & & & & & & .766 & \\
\hline Statement 27 & & & & & & .533 & \\
\hline Statement 28 & & & & & & .705 & \\
\hline Extraction Method: Principal Component Analysis. \\
Rotation Method: Varimax with Kaiser Normalization. \\
\hline Rotation converged in 9 iterations. & & \\
\hline
\end{tabular}


As per Table 5 reflects the principal component which was undertaken for the study, it reflects the matrix of the factor loading for each variable. Effective factor loading should be greater than 0.5 according to hair et.al, 2015. Thus coefficients below the value of 0.5 were suppressed and all those coefficients which had the value $\geq 0.5$ were taken.

Table 6 reflects seven factors which were successfully extracted using factor analysis which were assigned as factors affecting the perception of millennial job seekers. The Table shows the names of the factors. First factor consisted of variables such as accurate information, relevant information, consistent information etc) hence it was named as Information Quality. Second factor consisted of variables such as (career information, awareness of future career prospective, better career decision, increased knowledge of future openings) hence it was named as Prospective career Opportunities. Third factor consisted of variables such as (finding appropriate jobs, portal is effective to look for jobs, portal gives useful information) hence it was named as Perceived usefulness. Fourth factor consisted of items like easy navigation, response time of website, job seeking ways hence it was named as System Quality. Fifth factor consisted of variables such as interaction with portal, ease of use, become skillful at using the website) hence it was named as Perceived ease of use. Sixth factor consisted of variables such as (alert services, employer review feature, and widest facility) hence it was named as Extended services. Seventh factor consisted of variables such as portal is secure, privacy of information, which was named as Perceived Trustworthiness.

Table 6 Factor Loading and Cronbach's Alpha

\begin{tabular}{|c|c|c|c|}
\hline Factor & Items & $\begin{array}{c}\text { Factor } \\
\text { Loading }\end{array}$ & $\begin{array}{c}\text { Cronbach's } \\
\text { alpha }\end{array}$ \\
\hline \multirow{5}{*}{ Information Quality } & $\begin{array}{l}\text { The job portal provides accurate } \\
\text { information about the job. }\end{array}$ & 0.887 & \multirow{5}{*}{0.804} \\
\hline & $\begin{array}{l}\text { The job portal provides relevant } \\
\text { information about the job. }\end{array}$ & 0.699 & \\
\hline & $\begin{array}{l}\text { The job portal provides consistent } \\
\text { information about the job. }\end{array}$ & 0.615 & \\
\hline & $\begin{array}{l}\text { The job portal provides up to date } \\
\text { information ab } \\
\text { out the job. }\end{array}$ & 0.549 & \\
\hline & $\begin{array}{l}\text { The job portal provides appropriate } \\
\text { information about the job. }\end{array}$ & 0.546 & \\
\hline \multirow{5}{*}{$\begin{array}{l}\text { Prospective Career } \\
\text { Information }\end{array}$} & $\begin{array}{l}\text { Using job portal help me to get current } \\
\text { career information }\end{array}$ & 0.517 & \multirow{5}{*}{0.798} \\
\hline & $\begin{array}{l}\text { The use of job portal has made me more } \\
\text { aware of future career opportunities }\end{array}$ & 0.694 & \\
\hline & $\begin{array}{l}\text { I make better career decisions because of } \\
\text { information I get on job portal. }\end{array}$ & 0.779 & \\
\hline & $\begin{array}{l}\text { I am more likely to find career information } \\
\text { by visiting job portal than through other } \\
\text { sources of information. }\end{array}$ & 0.748 & \\
\hline & $\begin{array}{l}\text { By visiting job portal, I have increased my } \\
\text { knowledge of future career opportunities }\end{array}$ & 0.673 & \\
\hline
\end{tabular}




\begin{tabular}{|c|c|c|c|}
\hline \multirow{3}{*}{ Perceived Usefulness } & $\begin{array}{l}\text { Using job portal increase my chances of } \\
\text { finding an appropriate job. }\end{array}$ & 0.763 & \multirow{3}{*}{0.796} \\
\hline & Using job portal is effective to look for job. & 0.787 & \\
\hline & $\begin{array}{l}\text { Overall, using job portal is a useful way to } \\
\text { look for a job. }\end{array}$ & 0.628 & \\
\hline \multirow{3}{*}{ System Quality } & $\begin{array}{l}\text { The job portal has an easy navigation to job } \\
\text { information. }\end{array}$ & 0.676 & \multirow{3}{*}{0.683} \\
\hline & $\begin{array}{l}\text { The response time of the job portal is } \\
\text { proper. }\end{array}$ & 0.729 & \\
\hline & $\begin{array}{l}\text { The job portal provides different ways of } \\
\text { job seeking. }\end{array}$ & 0.555 & \\
\hline \multirow{3}{*}{ Perceived ease of use } & $\begin{array}{l}\text { Interacting with the job portal does not } \\
\text { require a lot of my mental effort. }\end{array}$ & 0.814 & \multirow{3}{*}{0.517} \\
\hline & I find the job portal to be easy to use. & 0.616 & \\
\hline & $\begin{array}{l}\text { It would be easy for me to become skillful } \\
\text { at Using job portal. }\end{array}$ & 0.555 & \\
\hline \multirow{3}{*}{ Extended Services } & $\begin{array}{l}\text { The job portal provides email alert services } \\
\text { to notify the job seekers. }\end{array}$ & 0.766 & \multirow{3}{*}{0.714} \\
\hline & $\begin{array}{l}\text { The job portal provides employer review } \\
\text { feature to enable the job applicants in taking } \\
\text { appropriate decision. }\end{array}$ & 0.533 & \\
\hline & $\begin{array}{l}\text { Job portal provides with the widest and } \\
\text { comprehensive job search facility. }\end{array}$ & 0.705 & \\
\hline \multirow{3}{*}{$\begin{array}{l}\text { Perceived } \\
\text { Trustworthiness }\end{array}$} & I believe, using job portal is secure. & 0.671 & \multirow{3}{*}{0.614} \\
\hline & $\begin{array}{l}\text { I trust the ability of job portal to protect my } \\
\text { privacy. }\end{array}$ & 0.674 & \\
\hline & $\begin{array}{l}\text { I am not worried about the security of the } \\
\text { job portal. }\end{array}$ & 0.615 & \\
\hline
\end{tabular}

\subsection{Hypothesis Testing - Analysis of Variance}

Post identification and analysis of the factors using the factor analysis technique, it is also vital to examine the significant difference in perception of millennial job seekers of different age group. One way ANOVA is used for this study. ANOVA is a collection of statistical technique to analyse the differences among group mean.

$\mathbf{H}_{\mathbf{1}}$ : There is significant difference in perception of information quality among different age group of job seekers.

$\mathbf{H}_{2}$ : There is significant difference in perception of prospective career information among different age group of job seekers.

$\mathbf{H}_{3}$ : There is significant difference in perceived usefulness among different age group of job seekers.

$\mathbf{H}_{\mathbf{4}}$ : There is significant difference in perception of system quality among different age group of job seekers.

$\mathbf{H}_{5}$ : There is significant difference in perceived ease of use among different age group of job seekers.

$\mathbf{H}_{6}$ : There is significant difference in perception of extended services among different age group of job seekers.

$\mathbf{H}_{7}$ : There is significant difference in perceived trustworthiness among different age group of job seekers. 
Table 7 above depicted comparative analysis of three different age group with respect to all the factors affecting the millennial job seekers towards job portals. In Table 7, $P$ value for Perceived Usefulness, Perceived Ease of Use and Extended Services was $0.004,0.030$ and 0.026 respectively. All these values are below the significance value of 0.05 . This shows that there is a significant difference in perceived usefulness, perceived ease of use and extended services with respect to age group of millennial job seekers.

Table 7 ANOVA: Analysis of Variance of Job Seekers

\begin{tabular}{|c|c|c|c|c|c|c|c|}
\hline & & $\begin{array}{c}\text { Sum of } \\
\text { Squares } \\
\end{array}$ & df & $\begin{array}{c}\text { Mean } \\
\text { Square }\end{array}$ & $\mathbf{F}$ & Sig. & Hypothesis \\
\hline \multirow{3}{*}{ Information Quality } & Between Groups & 63.132 & 3 & 21.044 & \multirow{3}{*}{2.164} & \multirow{3}{*}{0.097} & \multirow{3}{*}{$\mathrm{H}_{1}$ Rejected } \\
\hline & Within Groups & 1021.290 & 105 & 9.727 & & & \\
\hline & Total & 1084.422 & 108 & & & & \\
\hline \multirow{3}{*}{$\begin{array}{l}\text { Prospective Career } \\
\text { Information }\end{array}$} & Between Groups & 61.758 & 3 & 20.586 & \multirow{3}{*}{2.025} & \multirow{3}{*}{0.115} & \multirow{3}{*}{$\mathrm{H}_{2}$ Rejected } \\
\hline & Within Groups & 1067.270 & 105 & 10.164 & & & \\
\hline & Total & 1129.028 & 108 & & & & \\
\hline \multirow{3}{*}{$\begin{array}{l}\text { Perceived } \\
\text { Usefulness }\end{array}$} & Between Groups & 53.804 & 3 & 17.935 & \multirow{3}{*}{4.789} & \multirow{3}{*}{0.004} & \multirow{3}{*}{$\begin{array}{c}\mathrm{H}_{3} \\
\text { Accepted }\end{array}$} \\
\hline & Within Groups & 393.205 & 105 & 3.745 & & & \\
\hline & Total & 447.009 & 108 & & & & \\
\hline \multirow{3}{*}{ System Quality } & Between Groups & 18.464 & 3 & 6.155 & \multirow{3}{*}{1.310} & \multirow{3}{*}{0.275} & \multirow{3}{*}{$\mathrm{H}_{4}$ Rejected } \\
\hline & Within Groups & 493.114 & 105 & 4.696 & & & \\
\hline & Total & 511.578 & 108 & & & & \\
\hline \multirow{3}{*}{$\begin{array}{l}\text { Perceived ease of } \\
\text { use }\end{array}$} & Between Groups & 37.577 & 3 & 12.526 & \multirow{3}{*}{3.108} & \multirow{3}{*}{0.030} & \multirow{3}{*}{$\begin{array}{c}\mathrm{H}_{5} \\
\text { Accepted }\end{array}$} \\
\hline & Within Groups & 423.175 & 105 & 4.030 & & & \\
\hline & Total & 460.752 & 108 & & & & \\
\hline \multirow{3}{*}{ Extended Services } & Between Groups & 37.956 & 3 & 12.652 & \multirow{3}{*}{3.209} & \multirow{3}{*}{0.026} & \multirow{3}{*}{$\begin{array}{c}\mathrm{H}_{6} \\
\text { Accepted }\end{array}$} \\
\hline & Within Groups & 414.008 & 105 & 3.943 & & & \\
\hline & Total & 451.963 & 108 & & & & \\
\hline \multirow{3}{*}{$\begin{array}{l}\text { Perceived } \\
\text { Trustworthiness }\end{array}$} & Between Groups & 30.203 & 3 & 10.068 & \multirow{3}{*}{1.903} & \multirow{3}{*}{0.134} & \multirow{3}{*}{$\mathrm{H}_{7}$ Rejected } \\
\hline & Within Groups & 550.121 & 104 & 5.290 & & & \\
\hline & Total & 580.324 & 107 & & & & \\
\hline
\end{tabular}

\subsection{Post Hoc Test}

ANOVA is used to identify sample mean that are significantly different from each other. The results of one way - ANOVA do not indicate which group differs from other, so we conduct POST HOC Test where Tukey's test was conducted to compare the means and know exactly where the difference lies among the age groups.

Table 8 of Turkeys test reflects where exactly the significant difference among age group lies. In case of perceived usefulness, $P$ value is 0.004 and 0.027 which is less than 0.05 hence age group of below 18, 25 - 28 and 22- 24 are significantly different. In case Perceived ease of use $P$ value is 0.021 which is less than 0.05 hence, age 
group of below $18 \& 25-28$ are significantly different. In case Extended Service $P$ value is 0.02 and 0.01 which is less than 0.05 hence, age group of below $18 \& 25$ 28 are significantly different.

Table 8 Tukey HSD: Post Hoc Output with respect to Perceived Usefulness, Perceived Ease of Use and Extended Services

\begin{tabular}{|c|c|c|c|c|c|c|c|}
\hline & \multirow[b]{2}{*}{ (I) Age } & \multirow[b]{2}{*}{ (J) Age } & \multirow{2}{*}{$\begin{array}{c}\text { Mean Difference } \\
\text { (I-J) }\end{array}$} & \multirow{2}{*}{$\begin{array}{l}\text { Std. } \\
\text { Error }\end{array}$} & \multirow{2}{*}{ Sig. } & \multicolumn{2}{|c|}{$\begin{array}{l}\text { 95\% Confidence } \\
\text { Interval }\end{array}$} \\
\hline & & & & & & $\begin{array}{l}\text { Lower } \\
\text { Bound }\end{array}$ & $\begin{array}{l}\text { Upper } \\
\text { Bound }\end{array}$ \\
\hline \multirow{12}{*}{$\begin{array}{l}\text { Perceived } \\
\text { usefulness }\end{array}$} & \multirow{3}{*}{$\begin{array}{c}\text { Below } \\
18\end{array}$} & $18-21$ & -2.66667 & 1.24913 & 0.149 & -5.9277 & 0.5944 \\
\hline & & 22- 24 & $-3.25373^{*}$ & 1.142 & $\mathbf{0 . 0 2 7}$ & -6.2351 & -0.2724 \\
\hline & & $25-28$ & $-4.07407^{*}$ & 1.1777 & 0.004 & -7.1486 & -0.9995 \\
\hline & \multirow{3}{*}{$18-21$} & $\begin{array}{c}\text { Below } \\
18\end{array}$ & 2.66667 & 1.24913 & 0.149 & -0.5944 & 5.9277 \\
\hline & & $22-24$ & -0.58706 & 0.6066 & 0.768 & -2.1707 & 0.9966 \\
\hline & & $25-28$ & -1.40741 & 0.67139 & 0.161 & -3.1602 & 0.3454 \\
\hline & \multirow{3}{*}{$22-24$} & \begin{tabular}{|c|} 
Below \\
18 \\
\end{tabular} & $3.25373^{*}$ & 1.142 & 0.027 & 0.2724 & 6.2351 \\
\hline & & $18-21$ & 0.58706 & 0.6066 & 0.768 & -0.9966 & 2.1707 \\
\hline & & $25-28$ & -0.82034 & 0.44112 & 0.252 & -1.972 & 0.3313 \\
\hline & \multirow{3}{*}{$25-28$} & $\begin{array}{c}\text { Below } \\
18 \\
\end{array}$ & $4.07407^{*}$ & 1.1777 & 0.004 & 0.9995 & 7.1486 \\
\hline & & $18-21$ & 1.40741 & 0.67139 & 0.161 & -0.3454 & 3.1602 \\
\hline & & $22-24$ & 0.82034 & 0.44112 & 0.252 & -0.3313 & 1.972 \\
\hline \multirow{12}{*}{$\begin{array}{l}\text { Perceived } \\
\text { Ease of use }\end{array}$} & \multirow{3}{*}{$\begin{array}{c}\text { Below } \\
18\end{array}$} & $18-21$ & -3 & 1.29587 & 0.101 & -6.3831 & 0.3831 \\
\hline & & $22-24$ & -2.87065 & 1.18472 & 0.079 & -5.9635 & 0.2223 \\
\hline & & $25-28$ & $-3.59259^{*}$ & 1.22175 & 0.021 & -6.7822 & -0.403 \\
\hline & \multirow{3}{*}{$18-21$} & $\begin{array}{c}\text { Below } \\
18 \\
\end{array}$ & 3 & 1.29587 & 0.101 & -0.3831 & 6.3831 \\
\hline & & $22-24$ & 0.12935 & 0.62929 & 0.997 & -1.5135 & 1.7722 \\
\hline & & $25-28$ & -0.59259 & 0.69651 & 0.83 & -2.4109 & 1.2257 \\
\hline & \multirow{3}{*}{$22-24$} & $\begin{array}{c}\text { Below } \\
18\end{array}$ & 2.87065 & 1.18472 & 0.079 & -0.2223 & 5.9635 \\
\hline & & $18-21$ & -0.12935 & 0.62929 & 0.997 & -1.7722 & 1.5135 \\
\hline & & $25-28$ & -0.72195 & 0.45763 & 0.396 & -1.9166 & 0.4728 \\
\hline & \multirow{3}{*}{$25-28$} & $\begin{array}{c}\text { Below } \\
18\end{array}$ & $3.59259^{*}$ & 1.22175 & 0.021 & 0.403 & 6.7822 \\
\hline & & $18-21$ & 0.59259 & 0.69651 & 0.83 & -1.2257 & 2.4109 \\
\hline & & $22-24$ & 0.72195 & 0.45763 & 0.396 & -0.4728 & 1.9166 \\
\hline \multirow{10}{*}{ Extended Service } & \multirow{3}{*}{$\begin{array}{c}\text { Below } \\
18\end{array}$} & $18-21$ & -3 & 1.28175 & 0.095 & -6.3462 & 0.3462 \\
\hline & & $22-24$ & $-3.45274^{*}$ & 1.17182 & 0.02 & -6.512 & -0.3935 \\
\hline & & $25-28$ & $-3.62963^{*}$ & 1.20845 & $\mathbf{0 . 0 1 7}$ & -6.7845 & -0.4748 \\
\hline & \multirow{3}{*}{$18-21$} & $\begin{array}{c}\text { Below } \\
18 \\
\end{array}$ & 3 & 1.28175 & 0.095 & -0.3462 & 6.3462 \\
\hline & & $22-24$ & -0.45274 & 0.62244 & 0.886 & -2.0777 & 1.1722 \\
\hline & & $25-28$ & -0.62963 & 0.68892 & 0.797 & -2.4282 & 1.1689 \\
\hline & \multirow{3}{*}{$22-24$} & \begin{tabular}{|c|} 
Below \\
18 \\
\end{tabular} & $3.45274^{*}$ & 1.17182 & $\mathbf{0 . 0 2}$ & 0.3935 & 6.512 \\
\hline & & $18-21$ & 0.45274 & 0.62244 & 0.886 & -1.1722 & 2.0777 \\
\hline & & $25-28$ & -0.17689 & 0.45264 & 0.98 & -1.3586 & 1.0048 \\
\hline & $25-28$ & Below & $3.62963^{*}$ & 1.20845 & 0.017 & 0.4748 & 6.7845 \\
\hline
\end{tabular}




\begin{tabular}{|l|c|c|c|c|c|c|c|}
\hline & 18 & & & & & \\
\cline { 2 - 7 } & $18-21$ & 0.62963 & 0.68892 & 0.797 & -1.1689 & 2.4282 \\
\cline { 2 - 7 } & $22-24$ & 0.17689 & 0.45264 & 0.98 & -1.0048 & 1.3586 \\
\hline
\end{tabular}

\section{Findings and Conclusion}

From the analysis above, we identified seven vital factors which determine the millennial job seekers perception towards job portals in the job search activity with special reference to naukri.com. Providing the information to job seeker about the relevant open positions is not only one of the factor to build the perception towards job portal. Various other factors which influence the perception are Perceived Usefulness, Perceived Ease of use, Extended Services, Prospective career opportunities, System quality and Perceived Trustworthiness.

The study also focused to identify significant difference in age group towards job seekers perception. It showed that there is a significant difference among different age group of job seekers with respect to Perceived Usefulness, Perceived Ease of Use and Extended services. This shows that millennial job seekers are tech savvy and expects the job portal to be easy to use with low mental efforts to be required in job search and to enable them to become skillful in using it works to build the perception to it.

Today the customers want extra benefit, the feature of extended services enables them to meet the quest of the job seekers. They can access the mails of recent job opening, which make the job search and job application activity more prompt and quick. Thus study gives insight of job seekers perception which should be incorporated by the job portals for their working.

\section{Limitations and Future Scope}

The study was only limited to one of the largest recruitment job portals of India, however generalizing of the results would be inappropriate. With respect to the customer base it reflected the perception of job seekers only and the services provided to recruiters were ignored. Though the sample size is acceptable, but it needs to be increased along with other management students of different Universities to get exact picture about the perception of students. Even the geographical area for the study can be multi state. Further research on the perception of job seekers can be carried forward with the comparative analysis of different job portals and different location and for some specific functional area.

\section{References}

1. Allen, D. G., Mahto, R., \& Otondo, R. F. 'Web-based Recruitment: Effects of information, organizational brand, and attitudes toward a web site on applicant attraction', Journal of Applied Psychology, 92, 2007, 1696-1708.

2. Ashok Kumar and Priyanka, " A study on adoption of E-recruitment using Technology Acceptance Model (TAM) with reference to graduating students in universities in Bahrain", International Journal of Advance Research in Computer Science and Management Studies 2(9), 2014, 377-383.

3. Avinash Kapse S, Vishal Patil S, Nikhil Patil V. E-Recruitment, International Journal of Engineering and Advanced Technology (IJEAT). 1(4), 2012, 82-86. 
4. Barber, A.E., Recruiting employees: Individual and organizational perspectives. Thousand Oaks, CA: SAGE Publications 1998.

5. Banerjee, Pratyush \& Tiwari, Abhay. 'Factors Affecting Job-Seekers' Perceived Credibility Of Online Job Advertisements': A Review. Asia Pacific Journal of Research in Business Management. (4), 2013, 1-17.

6. Chapman, Derek S., \& Webster, J. The use of technologies in the recruiting, screening, and selection processes for job candidates. International Journal of Selection and Assessment, 2003, 113-120.

7. Crossley, C.D. and Highhouse, S. (2005) 'Relation of job search and choice process with subsequent satisfaction', Journal of Economic Psychology, (2), 2005, 255-268.

8. Dhamija P., "E-Recruitment: A Roadmap Towards E-Human Resource Management", Journal of Arts, Science \& Commerce, 3(2), 2012, 33 - 39

9. Edgley, K. The best job in the world may be one click away. The Times, No. 11, (1995), October.

10. Hair, J. F., Anderson, R. E., Tatham, R. L. \& Black, W. C., 'Multivariate data analysis', (5th Ed). New Jersey: Prentice Hall International, 1998.

11. Jack Walker, H., Feild, H.S., Giles, W.F., Bernerth, J.B. and Short, J.C., 'so what do you think of the organization? A contextual priming explanation for recruitment web site characteristics as antecedents of job seekers' organizational image perceptions', Organizational Behavior and Human Decision Processes. (2), 2011, 165-178.

12. Prabjot Kaur., "E-recruitment: A conceptual study $\square$, International Journal of Applied Research, 1(8), 2015, 78-82.

13. Lee I., "The evolution of E-Recruiting: A content analysis of Fortune 100 Career Websites". Journal Electronic Commerce in Organizations, 3(3), 2005, 57-68.

14. Lievens F, Harris MM Research on Internet recruiting and testing: Current status and future directions. International Review of Industrial and Organizational Psychology. 16, 2003, 131-165.

15. Moghaddam H. A., Rezaei S., \& Muslim A. Examining job seerker's perception and behavior intention towards online recruitment: A PLS Path modeling approach. International Journal for Global Business Advancement, 8(3), 2013 , $1-21$

16. Patwardhan U.B. Perception of job seekers towards Monster.com as an online recruitment job seeking avenue. 2016

17. Thompson, L.F., Braddy, P.W., \& Wuensch, K.L. E-recruitment and the benefits of organizational web appeal. Computers in Human Behaviour, 24(5), 2008, 2384-2398.

18. Zusman, R., and Landis, R "Applicant Preferences for Web-Based versus Traditional Job Postings", Computers in Human Behavior, 18(3), 2002, 285-29

\section{About Our Authors}

Seema Wadhawan carries with her 7 years of experience in academics and nearly 9 years of experience in corporate, talent acquisition domain. She is currently working as assistant professor with Gitarattan International Business School, affiliated to Guru Gobind Singh Indraprastha University, Delhi. Her areas of interest include 
organization behavior, talent acquisition and Performance management. She is currently pursuing her doctoral research on Online recruitment techniques from Amity University, UP, India. She has contributed several research papers in reputed national and international management journals. She has also presented papers in national and international conferences and won best paper award. As a part of pursuit for academic excellence, she has attended several seminars, workshops and conferences related to OB, HR and others.

Smrita Sinha possess more than 18 years of teaching experience. She completed her PhD from Gautam Buddha Technical University, Lucknow and is NET qualified. She is presently teaching as Business Communication Head and Coordinator at Amity Business School, Amity University, Noida. She has published several case studies in ECCH and has many research papers and articles in National and International Journals of repute. She presented her research paper at Szent Istvan University, Hungary. She has authored three books and has been the e-content writer for post graduate project for the country under the prestigious National Project known as 'e-PG Pathshala under the UGC, NMEICT initiative of MHRD, Govt of India. Her area of interest includes Organization Culture, Organization Behavior and Business Communication 